\title{
Injury characteristics in women in relation to their menopausal status
}

\section{Charakterystyka urazów u kobiet w zależności od stanu menopauzalnego}

\author{
Dariusz Timler' ${ }^{1}$ Katarzyna Bogusiak², Anna Kasielska-Trojan³, Marcin Madziała, tukasz Szarpak ${ }^{4}$ \\ ${ }^{1}$ Department of Emergency Medicine and Disaster Medicine, Medical University of Lodz \\ 2Department of Craniomaxillofacial and Oncological Surgery, Medical University of Lodz \\ ${ }^{3}$ Medical University of Lodz \\ ${ }^{4}$ Collegium Masoviense, Wyższa Szkoła Nauk o Zdrowiu
}

Przegląd Menopauzalny 2013; 3: 266-270

\section{Summary}

Aim of the study: Analysis of the frequency and characteristics of injuries in women depending on their menopausal status.

Material and methods: The retrospective study included 1362 women treated in the Copernicus Memorial Hospital in Lodz in 2011 because of the injury. The population was divided according to the menopausal status: women of the reproductive age (group I), women in the peri-menopausal period (group II) and postmenopausal women (group III). The analysis included the time of injury, its type and cause, duration of hospitalization, and mortality.

Results: The most common trauma in the examined women were head injuries. The groups differed in terms of the causes of injury. Postmenopausal women were hospitalized significantly longer than women in the reproductive age $(p<0.001)$ and in the peri-menopausal period $(p<0.001)$. They were also characterized by the highest mortality.

Conclusions: The physiological changes in women's body, related to their menopausal status are reflected in the characteristics of injuries occurring in different periods of life. Differences in trauma causes were observed - in women of the reproductive age, the most common causes were traffic accidents while in those in peri- and postmenopausal periods - same-level falls. It may be associated with the fact that in peri- and postmenopausal women falls may result in low-energy osteoporotic fractures needing hospitalization.

Key words: menopause, trauma, age.

\section{Streszczenie}

Cel pracy: Analiza częstości i charakterystyki urazów w populacji kobiet hospitalizowanych z tego powodu, w zależności od ich statusu menopauzalnego.

Materiały i metody: Badaniem retrospektywnym objęto 1362 pacjentki leczone z powodu urazów w Wojewódzkim Szpitalu Specjalistycznym im. Mikołaja Kopernika w Łodzi w 2011 r. Badaną populację kobiet podzielono zgodnie z ich statusem menopauzalnym: kobiety w wieku reprodukcyjnym (grupa I), w wieku okołomenopauzalnym (grupa II) oraz w wieku pomenopauzalnym (grupa III). W analizie uwzględniono czas doznanego urazu, jego rodzaj, przyczynę, czas hospitalizacji oraz śmiertelność.

Wyniki: Najczęściej występowały obrażenia głowy. Badane grupy różniły się pod względem częstości występowania poszczególnych przyczyn urazu. Kobiety w okresie pomenopauzalnym hospitalizowano istotnie statystycznie dłużej niż kobiety w okresie reprodukcyjnym $(p<0,001)$ i okołomenopauzalnym $(p<0,001)$, charakteryzowała je również najwyższa śmiertelność.

Wnioski: Fizjologiczne zmiany zachodzące w organizmie kobiet związane z ich statusem menopauzalnym znajdują odzwierciedlenie w charakterystyce obrażeń występujących w poszczególnych okresach życia. Ponadto uwagę zwraca różnica w przyczynach urazów - u kobiet w okresie reprodukcyjnym najczęściej są to wypadki komunikacyjne, a w pozostałych okresach - upadki na tym samym poziomie. Różnica ta może wynikać z faktu, że u kobiet $w$ wieku około- i pomenopauzalnym upadki mogą skutkować złamaniami niskoenergetycznymi związanymi z osteoporozą, wymagającymi leczenia szpitalnego.

Słowa kluczowe: menopauza, uraz, wiek. 


\section{Introduction}

In most European countries and also in Poland demographic transformation has been observed in recent years. It means changes in age structure of the society and increase in the proportion of the elderly. The changes do not affect women and men equally, but they predominate in women [1]. This fact contributes to the researchers' increasing interest in the health of the female population, especially postmenopausal women. Epidemiological analyses show that in Poland approximately $70-80 \%$ of deaths are caused by diseases of civilization, which include among others: heart diseases, cancers, injuries, traumas and poisonings. In medical literature many studies concerning influence of the menopausal state on the risk of heart diseases and different types of cancers can be found. However, little is known about the impact of menopausal state on the frequency of injuries. In recent years a slight decrease in the mortality rate of injured patients has been observed, mortal injuries constituted about $7 \%$ of all deaths reported in 2006. A decreasing trend is much more pronounced in male than female population [1]. For example, a fracture risk is higher in women than men, and according to some authors, it increases even twofold in those aged 60 years or older [2-4].

One of the most important causes of morbidity related to trauma in postmenopausal women is osteoporosis with associated fractures, especially hip, femur, spine and wrist fractures [5]. This results from the fact that the trabecular bone, found in the femur, is sensitive to the effects of estrogen, progesterone, and aging. Some studies have shown an association between a later onset of menopause and a higher risk of hip and wrist fractures, while other studies have not found such correlation $[6,7]$. Also, a rapid increase in fractures incidence was observed in women aged over 45 years [8]. Some authors claim that this rapid increase in fractures in women, that appear earlier that the mean age of menopause, may suggest a cause other than connected with menopausal state [9].

Due to the fact that there are only a few papers concerning this issue, the aim of this study was to analyze the frequency and characteristics of injuries in women depending on their menopausal status.

Tab. I. Characteristics of groups of patients with injuries

\begin{tabular}{lccc}
\hline \multirow{2}{*}{ Group } & \multicolumn{2}{c}{ Number of patients } & Mean age \pm SD \\
\cline { 2 - 3 } & $n$ & $\%$ & \\
\hline I & 353 & 25.9 & $30.16 \pm 7.78$ \\
\hline II & 210 & 15.4 & $51.56 \pm 3.83$ \\
\hline III & 799 & 58.7 & $76.62 \pm 10.16$ \\
\hline Total & 1362 & 100 & $60.71 \pm 21.95$ \\
\hline
\end{tabular}

\section{Material and methods}

The retrospective study included 1362 women treated in the Copernicus Hospital in Lodz in 2011 because of the injury. The population was divided according to their menopausal status: women of the reproductive age (group I), women in the peri-menopausal period aged over 45 years with irregular cycles or those less than 12 months since last menstruation (group II) and postmenopausal women - minimum 12 months since last menstruation (group III) (Tab. I). Medical charts were analyzed in the following aspects: patient's age, time of injury, its type and cause. Also duration of hospitalization and mortality were included in the analysis.

\section{Statistical analysis}

Testing for distribution normality was performed with W Shapiro-Wilk test. In cases of normal distribution, the means were compared with $t$ Student test, otherwise non-parametric Wilcoxon test was used. Correlations between the frequency of variables were checked with chi-square test with $p<0.05$ accepted as a level of significance. Kaplan-Meier survival analysis was used to measure the fraction of survivors, and univariate analysis was performed with log-rank and Wilcoxon-Gehan tests. Statistical analysis was done using Statistica 10 (StatSoft $^{\oplus}$, Tulsa, USA).

\section{Results}

Analysis of the incidence of injuries in the study groups with regard to the timing of accidents showed that in women in the reproductive age, injuries were most common between 14.00 and $14.59(n=29)$, and least frequent between 7.00 and $7.59(n=1)$. Among women in group II, the maximum rate of injuries was at 21.00-21.59 $(n=20)$ and in group III, between 20:00 and 20:59 (Fig. 1). Statistical analysis showed no significant difference in the timing of injuries between the groups ( $p>0.05$ ). The injuries were assigned to 4 groups with regard to the time of occurrence: night/morning time (0.00-5.59), forenoon (6.00-11.59), afternoon (12.00-17.59) and evening/night time (18.00-23.59). In all the analyzed groups of women, injuries were most frequent in the evening/night time (Tab. II).

Analysis of the occurrence of injuries throughout the year showed that in group I injuries were most frequent in October $(n=43)$, while least frequent in August $(n=18)$. In group II, the peak of accidents fell in July ( $n=24)$, and the biggest decline in the numbers of patients treated for injuries was observed in March, April and November ( $n=13)$ for each month). For women in group III, most cases were reported in April $(n=82)$, and the least in May $(n=53)$. Statistical analysis showed 

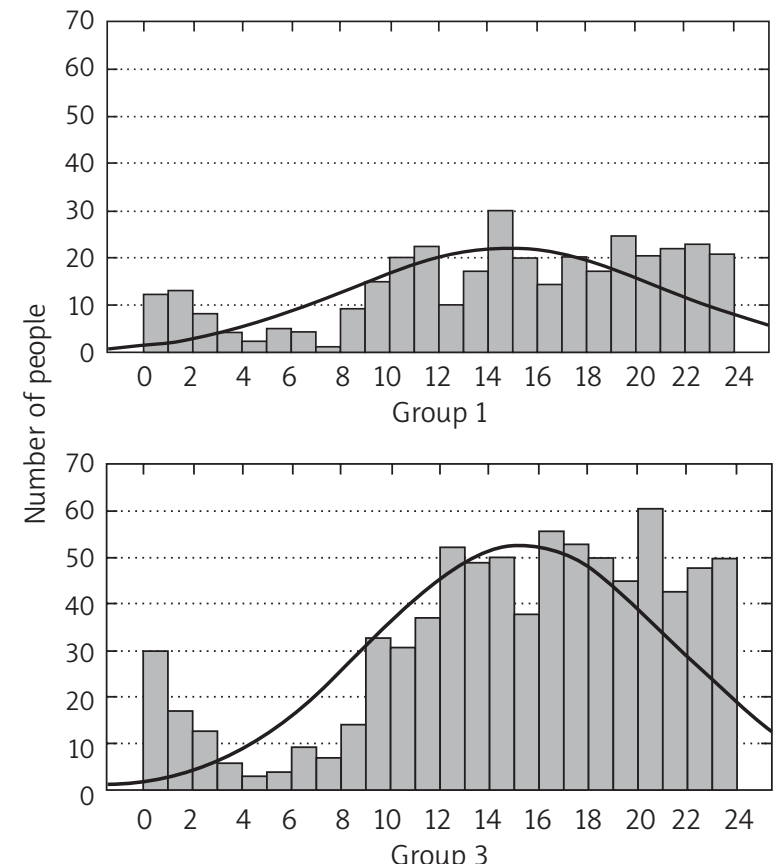

Tab. II. Distribution of the occurrence of injuries in the study groups according to the time of the day

\begin{tabular}{lccc}
\hline Time of a day & $\begin{array}{c}\text { Group I } \\
(n=353) \\
n(\%)\end{array}$ & $\begin{array}{c}\text { Group II } \\
(n=210) \\
n(\%)\end{array}$ & $\begin{array}{c}\text { Group III } \\
(n=799) \\
n(\%)\end{array}$ \\
\hline $0.00-5.59$ & $44(12)$ & $19(9)$ & $73(9)$ \\
\hline $6.00-11.59$ & $70(20)$ & $50(24)$ & $129(16)$ \\
\hline $12.00-17.59$ & $110(31)$ & $69(33)$ & $298(37)$ \\
\hline $18.00-23.59$ & $129(37)$ & $72(34)$ & $299(37)$ \\
\hline
\end{tabular}

Tab. IV. The frequency distribution of the occurrence of the injury depending on its location

\begin{tabular}{lccc}
\hline Type of trauma & Group I & Group II & Group III \\
& $n$ & $n$ & $n$ \\
\hline head trauma & 194 & 142 & 447 \\
\hline neck trauma & 89 & 33 & 24 \\
\hline chest trauma & 90 & 60 & 99 \\
\hline abdomen and pelvis trauma & 71 & 44 & 104 \\
\hline upper limb trauma & 93 & 64 & 206 \\
\hline lower limb trauma & 108 & 81 & 390 \\
\hline
\end{tabular}

no significant difference in the incidence of injuries with regard to months between the groups $(p>0.05)$. In addition, the incidence of injuries was compared depending on the day of the week of occurrence (Tab. III). Statistical analysis showed no significant difference in the incidence of injuries with regard to the day of the week between the two groups $(p>0.05)$.

The analysis of the incidence of injuries in different locations was also performed. In all groups, head in-

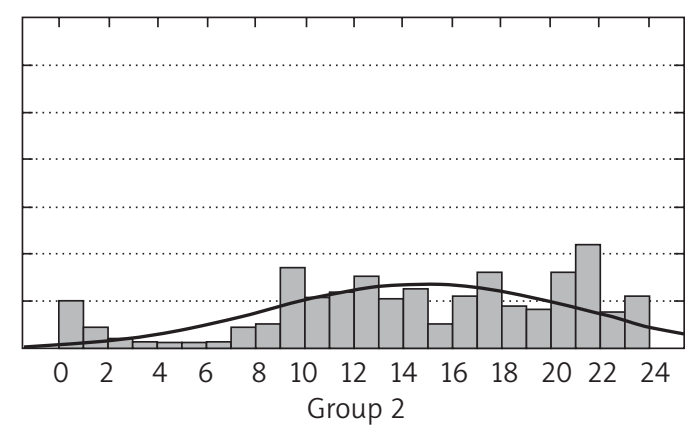

Fig. 1. Distribution of the incidence of injuries in each group according to the time

Tab. III. Distribution of injuries in the study groups, depending on the day of the week

\begin{tabular}{lccc}
\hline $\begin{array}{l}\text { Day } \\
\text { of the week }\end{array}$ & $\begin{array}{c}\text { Group I } \\
(n=353) \\
n(\%)\end{array}$ & $\begin{array}{c}\text { Group II } \\
(n=210) \\
n(\%)\end{array}$ & $\begin{array}{c}\text { Group III } \\
(n=799) \\
n(\%)\end{array}$ \\
\hline Monday & $54(15)$ & $41(20)$ & $116(15)$ \\
\hline Tuesday & $60(17)$ & $28(13)$ & $111(14)$ \\
\hline Wednesday & $55(16)$ & $34(16)$ & $121(15)$ \\
\hline Thursday & $50(14)$ & $27(13)$ & $136(17)$ \\
\hline Friday & $54(15)$ & $32(15)$ & $121(15)$ \\
\hline Saturday & $45(13)$ & $27(13)$ & $98(12)$ \\
\hline Sunday & $35(10)$ & $21(10)$ & $96(12)$ \\
\hline
\end{tabular}

Tab. V. The cause of injury

\begin{tabular}{lccc}
\hline Cause of injury & $\begin{array}{c}\text { Group I } \\
n(\%)\end{array}$ & $\begin{array}{c}\text { Group II } \\
n(\%)\end{array}$ & $\begin{array}{c}\text { Group III } \\
n(\%)\end{array}$ \\
\hline traffic accident & $198(56)$ & $68(32)$ & $275(35)$ \\
\hline fall from height & $35(10)$ & $17(8)$ & $82(10)$ \\
\hline fall on the same level & $71(20)$ & $78(37)$ & $321(40)$ \\
\hline assault & $38(11)$ & $23(11$ & $85(10)$ \\
\hline others & $11(3)$ & $24(12)$ & $36(5)$ \\
\hline
\end{tabular}

juries were the most frequent and leg injuries were the second most common location (Tab. IV).

Taking into account the cause of the injury, in groupl, traffic accidents were most frequent. In group II and III, same-level falls were reported most commonly. In group I, traffic injuries occurred significantly more frequently than in the other two groups $(p<0.001)(T a b . V)$.

Mortality in the whole study group reached $3.45 \%$ $(n=47)$. In group I and group II, 4 deaths were observed, 


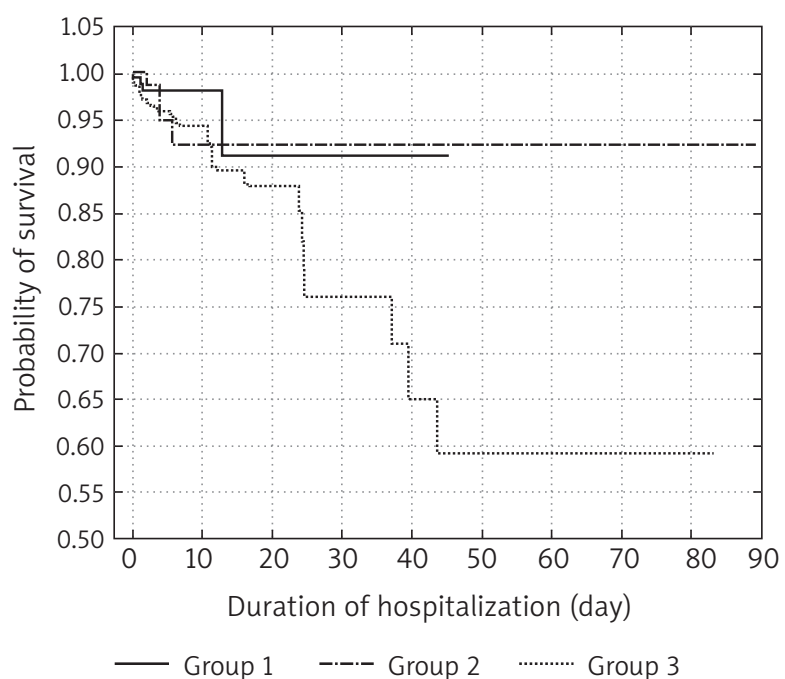

Fig. 2. Probability of survival (Kaplan-Meier)

while in group III - 39 deaths ( $p<0.001)$ (Fig. 2). Average length of hospital stay of all patients was 4.6 days, and for women in whom the therapeutic process failed - 8 days. Duration of hospitalization of women in group II did not differ significantly compared to group I ( $p=0.0623$ ). However, postmenopausal women were hospitalized for significantly longer than women in reproductive age $(p<0.001)$ and perimenopausal women $(p<0.001)$.

\section{Discussion}

In this study, no significant correlation between the timing of injury with regard to the time of the day, week or year, and menopausal status of women was observed. In all groups of women, injuries occurred most frequently between 18.00 and 23.59. However, Gordon et al. reported that the highest incidence of injury falls in the afternoon and evening hours (16.00 to 19.59) [10]. It was also shown that patients are twice as likely to be admitted to the hospital due to injuries in their leisure time than during their working hours [11]. In all the analyzed groups of women, lower-extremity and head injuries occurred most commonly. Literature data confirm that head and neck are the most common sites of injury, and injuries are less likely to occur in limbs and other parts of the body [11, 12]. In the present study, differences in the causes of injuries between the analyzed groups were shown. The most common cause of injuries among women of the reproductive age were traffic accidents. In groups II and III, incidence of samelevel falls, which include fainting, was notably high. The third most common cause of injuries in women, regardless of their menopausal status, was battery. The frequencies of particular causes of injuries reported in the literature vary widely. In the general population of women and men, traffic accidents are responsible for from $7.5 \%$ to about $70 \%$ of all injuries [12-14]. Differences in the incidence of various types of injuries with regard to gender [13-16] were also reported. Lima et al. highlight the high proportion of syncope in the pathogenesis of injury in women aged 70-74, as well as studies conducted among patients of more than 70 years of age, which showed a significant percentage of injuries due to falls on the same level [17].

The analysis showed that the largest group of patients hospitalized for trauma are postmenopausal women. In addition, patients in this period of life significantly more often suffer from fatal injuries, and are subject to longer hospitalization. This may be due to the presence of co-morbidities and/or increased susceptibility to infection [18]. Htadki et al. point out that in the elderly, hospitalization should be considered even in patients with minor injuries, taking into account the overall health of patients, and not only the severity of the injury [19]. Gowing suggests that older age of patients after trauma is associated with more complications mainly infections, and higher mortality [20].

\section{Conclusions}

In conclusion, physiological changes occurring in women related to their menopausal status are reflected in the characteristics of injuries in different periods of life. Regardless of the severity and location of injury, in postmenopausal women higher mortality and the need for extended hospitalization are observed. In addition, the difference in the causes of injuries should be noticed - in women of the reproductive age, traffic accidents are the most common cause, while in other periods of life - same-level falls. This may be due to the fact that in women of peri- and postmenopausal age falls can result in low-energy fractures related to osteoporosis, requiring hospitalization.

\section{References}

1. Gębska-Kuczerowska A, Miller M. Analiza sytuacji epidemiologicznej w Polsce w zakresie głównych problemów zdrowotnych. Post Nauk Med 2009; 4: 240-55.

2. Burge R, Dawson-Hughes B, Solomon DH, et al. Incidence and economic burden of osteoporosis-related fractures in the United States, 20052025. J Bone Miner Res 2007; 22: 465-75.

3. Nguyen ND, Ahlborg HG, Center JR, et al. Residual lifetime risk of fractures in women and men. J Bone Miner Res 2007; 22: 781-8.

4. Cummings SR, Cawthon PM, Ensrud KE, et al. BMD and risk of hip and nonvertebral fractures in older men: a prospective study and comparison with older women. J Bone Miner Res 2006; 21: 1550-6.

5. Lam SY, Baker HW, Seeman E, et al. Gynaecological disorders and risk factors in premenopausal women predisposing to osteoporosis: a review. Br J Obstet Gynaecol 1988; 95: 963-72.

6. Cooper GS, Sandler DP. Long-term effects of reproductive-age menstrual cycle patterns and postmenopausal fracture risk. Am J Epidemiol 1997; 145: 804-9.

7. Paganini-Hill A, Chao A, Ross RK, et al. Exercise and other factors in the prevention of hip fracture: the Leisure World Study. Epidemiology 1991; 2: $16-25$. 
8. Davey DA. The menopause and climacteric. In: Dewhurst's textbook of obstetrics and gynaecology for postgraduates. Whitfield CR (ed.). 5th ed. Blackwell Science Limited, Oxford 1995; 609-41.

9. Singer BR, McLauchlan GJ, Robinson CM, et al. Epidemiology of fractures in 15,000 adults: the influence of age and gender. J Bone Joint Surg $\mathrm{Br}$ 1998; 80: 243-8.

10. Gordon MW, Luke C, Robertson CE, et al. An audit of trauma deaths occurring in the accident and emergency department. Arch Emerg Med 1989; 6: 107-15.

11. Guly HR, Leighton G, Woodford M, et al. Trauma Audit and Research Network. The effect of working hours on outcome from major trauma. Emerg Med J 2006; 23: 276-80

12. Chalya PL, Gilyoma JM, Dass RM, et al. Trauma admissions to the intensive care unit at a reference hospital in Northwestern Tanzania. Scand J Trauma Resusc Emerg Med 2011; 19: 61

13. Batista AM, Marques LS, Batista AE. Urban-rural differences in oral and maxillofacial trauma. Braz Oral Res 2012; 26: 132-8.

14. Kool B, Raj N, Wainiqolo I, et al. Hospitalised and fatal head injuries in Viti Levu, Fiji: findings from an island-wide trauma registry (TRIP 4). Neuroepidemiology 2012; 38: 179-85.
15. Bogusiak K, Arkuszewski P. Characteristics and epidemiology of zygomaticomaxillary complex fractures. J Craniofac Surg 2010; 21: 1018-23.

16. Hernández-Tejedor A, García-Fuentes C, Toral-Vázquez D, et al. Differences in injury mechanism and pattern, severity and outcome of multiple trauma patients depending on gender. Med Intensiva 2008; 32: 337-41.

17. Lima RS, Campos ML. Profile of the elderly trauma victims assisted at an Emergency Unit. Rev Esc Enferm USP 2011; 45: 659-64.

18. Aktaş C, Eren SH, Eryilmaz M. Effects of co-morbid disease and drug consumption on trauma patients 65 years of age and older: a university emergency department experience. Ulus Travma Acil Cerrahi Derg 2008; 14: 313-7.

19. Hładki W, Brongel L, Lorkowski J. Injuries in the elderly patients. Przegl Lek 2006; 63 Suppl 5: 1-4.

20. Gowing R, Jain MK. Injury patterns and outcomes associated with elderly trauma victims in Kingston, Ontario. Can J Surg 2007; 50: 437-44. 